\title{
Baseline Study of Surface Water Chemistry of Badagry Creek, Lagos Nigeria
}

\author{
Aderinola O.J ${ }^{1}$, Adu A.A ${ }^{2}$, Kusemiju $V^{3}$ \\ Department of Zoology and Environmental Biology, Faculty of Science, Lagos State University, Ojo Lagos, Nigeria., P.O BOX 00001 , \\ Lagos state University Lagos
}

Department of Botany, Faculty of Science, Lagos State University, Ojo Lagos, Nigeria.

Department of Zoology and Environmental Biology, Faculty of Science, Lagos State University, Ojo Lagos, Nigeria

\begin{abstract}
The baseline hydrochemistry of Badagry Creek (Longitude2 ${ }^{\circ} 42^{\prime}$ and $3^{\circ} 23^{\prime} E$ and latitude $6^{\circ} 23^{\prime}$ and $6^{\circ} 28 N^{2}$ Lagos, Nigeria was investigated between 2007-2013 from four sampling stations to determine some physico-chemical parameters with the purpose of establishing a baseline data for Badagry creek. This is meant to set the record straight of future references. In doing this, the author followed the procedure of American Public Health Associations (APHA et. al) .The results show that physicochemical parameters did not differ significantly $(P>0.05)$ with respect to location. The surface water of the creek was characterized by high Turbidity (13.84 $\pm 5.73 \mathrm{NTU})$, Low Dissolved oxygen $(4.66 \pm 0.51 \mathrm{mg} / \mathrm{L}) \mathrm{High}$ Total Hardness as $\mathrm{CaC0}_{3}(1153.74 \pm 2130.60 \mathrm{mg} / \mathrm{L}) \mathrm{High}$ Total Hardness as $\mathrm{MgCO}_{3},(828.47 \pm 2252.20 \mathrm{mg} / \mathrm{L}) ;$ High Conductivity, (2366.33 $\left.\pm 3449.59 \mu \mathrm{S} / \mathrm{cm}\right)$, High Chemical Oxygen Demand (603.26 \pm 457.65$)$ High Biochemical Oxygen Demand $(152.75 \pm 89.05 \mathrm{mg} / \mathrm{L})$. The levels were above the maximum allowable levels set by Federal Environmental Protection Agency (FEPA) and WHO. Analysis of Variance equally revealed that the parameters were significantly high (p<0.05) and different among the study stations. Also the values of the heavy metals recorded were significantly higher when compared with international standards set by both FEPA and WHO. The trace metals analyzed includes Cadmium Chromium Lead (Copper and Zinc all in $\mathrm{mg} / \mathrm{L}$ respectively. Consequently, continuous monitoring of these parameters in the Creek is highly recommended.
\end{abstract}

Keywords: Badagry creeks, Physico-chemical parameters, trace metals Base line, Lagos Nigeria

\section{Introduction}

The continuous influx of people and rapid development that is fast taking place in this city has called for concern and one cannot but ponders on what the implication could be on the pressure on aquatic environment. This is because most of the people are settling along the coastline stretch. Consequently, most of the domestic wastes and sewages emanating from various homes end up in the creek as many villages around do not have private latrines and the creek invariably becomes the sink for human waste. Also, scattered all over the city are cottage industries such as processing mills and a host of artisan's workshops. Thus when rainfalls, substances such as ions and other substances are carried into the creek via rainfall and may result to pollution to the detriment of drinking water, recreational users and others users of the creek (Chandler, 1994; Ellis and Hvitved-Jacobsen, 1996). Thus the contamination of the creek from point and nonpoint sources as well as pollution of the creek by anthropogenic activities continues to impair watercourses (Karr and Chu, 2000; McCormick and Cairns, 1994; Moog and Chovanec, 2000).

Human settlements, industrial development, agriculture, deforestation, that is taken place around the city may have significantly impact on the physical and ecological features of the creek. It known that variations in Physico-chemical factors have a profound effect on the distribution and population density of both fauna and flora ((Mahboob, 1986, 1992; Mahboob et al., 1988a,b, 1992; Latif, 1990; Hassan, 1998; Mahboob and Sheri, 2001).

This study was undertaken to provide some baseline information on the ecology of the Creek. Because research studies on the aspects of the creeks ecology is of great importance in the developing resources of a water body.

\section{Materials and Methods}

\section{Study Area}

Badagry is an ancient city founded in the $15^{\text {th }}$ century around 1425.It was also reported that Badagry was one of the earliest international ports in the country and one of the earliest gateways for international trade. Other historical attributes includes the first town in west Africa to become urbanized, the first town not only in Nigeria but also through out old west Africa to easily boast of a two story building built in 1845 which still stands on the site of the original church yard till today and also serve as "Canterbury of Nigeria "where Christianity was first preached in 1842 and many more. All of these attributes have opened up Badagry and thus lunched it a city of recognition by the entire world thus the desire to reside in this ancient city by lovers of nature.

The study was carried out at Badagry Creek (Longitude2 ${ }^{\circ}$ $42^{\prime}$ and $3^{\circ} 23^{\prime} \mathrm{E}$ and latitude $6^{\circ} 23^{\prime}$ and $6^{\circ} 28 \mathrm{~N}$. It is a long stretched of water body covering about a distance of 106.5 kilometers. The creek is bounded in the West by River Ajara and Queme, and in the East by Lagos lagoon and Harbour. In the South however, it is bounded by Atlantic Ocean and in the North by several nodal villages and towns.

The major sources of waters into the creek are River Queme and Nakoue lagoon .It is the combination of these two water bodies that form the Badagry creek which joins part of the continuous lagoon known as Osa lagoon that stretches from 


\section{International Journal of Science and Research (IJSR) \\ ISSN (Online): 2319-7064 \\ Index Copernicus Value (2013): 6.14 | Impact Factor (2015): 6.391}

Port Novo to Lagos. The creek finally opens into the Atlantic ocean via Lagos harbour in three channels.

Surrounding the Creek is white mangrove forest, sedges and ferns. The mangroves forest includes Rhizophora racemosa, Phoenix reclinata, Avicennia nitida, Typha australis, Dalbergia ecastaphyllum, Drepanocarpus lunatus. The sedges are Cyperus articulatus, Paspalum vaginatum and
Cyperus papyrus.However the dominant ferns are Achrosticum acereum, Marsilea species, Cylosorus species and Ceratopleris species. Other plants that can be found around the creek are dotted of palm tress and Raphia palms (Raphia hookeri) Fig.1 shows map of Badagry Creek and the sampling locations.

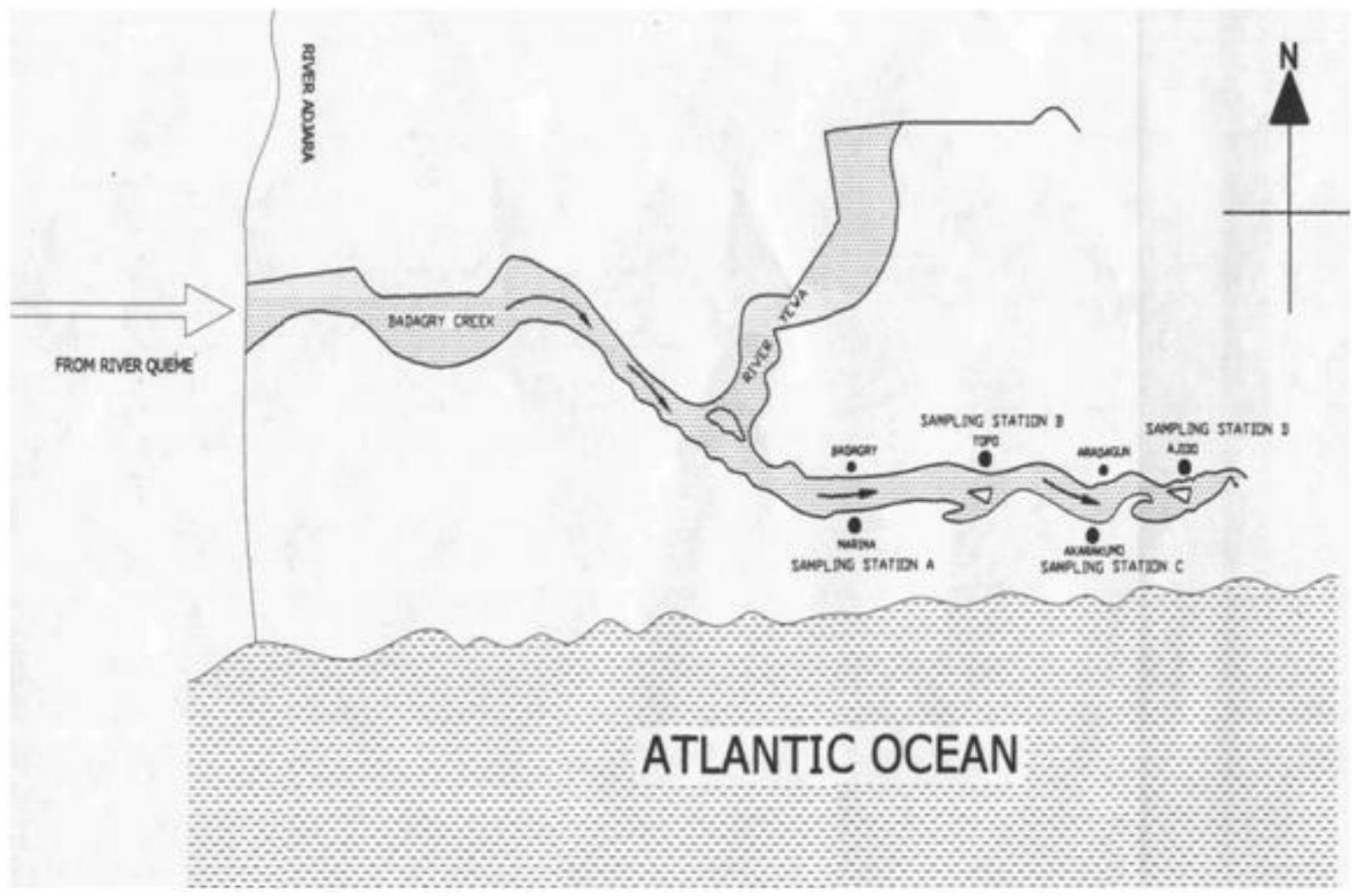

Figure 1: shows map of Badagry Creek and the sampling locations.

\section{Samples Collection}

The water samples were collected on monthly basis for a period of five year i.e., from January, 2007 through December, 2012 from the four sampling locations. Water samples were collected with $50 \mathrm{Cl}$ sterile polyvinyl chloride (PVC) plastic water bottles at a depth of 1 meter below the water surface. The samples were subsequently placed on ice in a cooler and transported to the laboratory for analysis. The following physico-chemical parameters were assessed using standard methods APHA et al, (1995), temperature, $\mathrm{pH}$, conductivity, Turbidity, Dissolved oxygen, Biochemical Oxygen Demands, Hardness, , phosphates, sulphates, and nitrate. PH was measured with the OORNING $\mathrm{pH}$ meter Model 7. Water temperature was measured with mercury in glass thermometer. The conductivity were determined with the portable conductivity meter, Turbidity was assessed with the Horiba water checker. Total hardness and calcium levels of samples were determined by complexometric titration with standard EDTA as titrant and Erichrome Black T as indicator (APHA, 1985). Phosphate was measured by the stannous chloride method; sulphate by the turbid meter method; nitrate by the Brucine method, alkalinity (titration with $0.02 \mathrm{~N}$ sulfuric acid to methyl orange endpoint); total hardness (titration to Erichrome Black-T endpoint with 0.01 $\mathrm{M}$ ethylenediaminetetraacetic acid);. While heavy metals were determined by Atomic Absorption Spectrophotometer (AAS)

\section{Results}

\section{Physical and Chemical Parameters}

The summary of the physical and chemical properties of the study locations is presented in the Table 1. Analysis of variance showed that there is know significance difference ( $\mathrm{P}>0.05$ ) between the sampling locations. This is possible because it is the same body of water that runs along the villages that served as sampling point of data collection (Fig. 1)

The mean values of Turbidity, Dissolved Oxygen, Conductivity, COD, BOD, Total Hardness as $\mathrm{CaCO}_{3}$ and lead were higher at some locations station than in other stations.

\section{Temperature}

The physico-chemical characteristics of the study stations are summarized in Table 1 . The total recorded mean temperature for Badagry Creek for the years 2007and 2012 was $27.59 \pm 1.12{ }^{\circ} \mathrm{C}$, with a minimum temperature of $26^{\circ} \mathrm{C}$ and a maximum of $31^{\circ} \mathrm{C}$. Among the sampling stations, Marina recorded the highest temperature of $28.04 \pm 1.12^{0} \mathrm{C}$ with the minimum of $27^{\circ} \mathrm{C}$ and the maximum of $31^{\circ} \mathrm{C}$. Akarakumo sampling station recorded the lowest mean 


\section{International Journal of Science and Research (IJSR) \\ ISSN (Online): 2319-7064 \\ Index Copernicus Value (2013): 6.14 | Impact Factor (2015): 6.391}

temperature of $27.28 \pm 0.950 \mathrm{C}$. with the minimum of $26^{\circ} \mathrm{C}$ and maximum of $30^{\circ} \mathrm{C}$ Table 1

\section{pH}

The total mean $\mathrm{pH}$ value recorded for the sampling stations for years 2007 and 2012 was $7.50 \pm 0.81$ with the minimum value of 6.4 and the maximum value of 12.0. Comparing the sampling station, Marina station had the highest mean $\mathrm{pH}$ value of $7.59 \pm 1.09$ with a minimum $\mathrm{pH}$ of 6.65 and a maximum of 12, where Akarakumo recorded the lowest mean $\mathrm{pH}$ value of $7.44 \pm 0.73$ with a minimum of 6.75 and a maximum of 10.10 (Table 1 ).

\section{Turbidity}

The total mean turbidity value of the Badagry Creek for the years 2007-2012 was put at $13.23 \pm 3.87$ NTU with the minimum value of $6.00 \mathrm{NTU}$ and the maximum of $28 \mathrm{NTU}$.

Considering the sampling stations, it will be observed that Topo station recorded the highest mean turbidity value of 13.0 \pm 5.15 NTU with a minimum of 8.00NTU and a maximum of 28.00NTU. Whereas for the same creek at Ajido sampling station the lowest turbidity value was recorded with the mean value of $12 \pm 3.26$ with the minimum of 6.00 and a maximum value of 21.00 NTU (Table 1).

\section{DISSOLVED OXYGEN}

The total mean oxygen concentration in Badagry Creek was $4.53 \pm 0.45 \mathrm{mg} / \mathrm{L}$ with minimum and maximum concentration of oxygen throughout 2007 and 2012 being 3.35 and 5.60 $\mathrm{mg} / \mathrm{L}$ respectively. As regards the sampling stations it was observed that Topo had the highest dissolved

Oxygen with a mean value of $4.55 \pm 0.52 \mathrm{mg} / \mathrm{L}$, a minimum value of 3.80 and a maximum of $5.60 \mathrm{mg} / \mathrm{L}$. This is followed by Akarakumo and Marina sampling stations where a mean Dissolved Oxygen value of $4.54 \pm 0.48 \mathrm{mg} / \mathrm{L}$ with a minimum value of $3.35 \mathrm{mg} / \mathrm{L}$ and a maximum level of $5.60 \mathrm{mg} / \mathrm{L}$, and $4.54 \pm 0.43 \mathrm{mg} / \mathrm{L}$ with a minimum of $4.00 \mathrm{mg} / \mathrm{L}$ and a maximum value of $5.40 \mathrm{mg} / \mathrm{L}$ were recorded respectively. However the lowest mean dissolved oxygen level was recorded in Ajido with a value of $4.49 \pm 0.38 \mathrm{mg} / \mathrm{L}$ with the minimum value of $4.00 \mathrm{mg} / \mathrm{L}$ and a maximum value of $5.20 \mathrm{mg} / \mathrm{L}$ (Table 1$)$.

\section{Biological Oxygen Demand (BOD).}

The total mean value of BOD recorded for Badagry creek was $134.93 \pm 74.17 \mathrm{mg} / \mathrm{L}$ with a minimum value of $9.0 \mathrm{mg} / \mathrm{L}$ and a maximum value of $380 \mathrm{mg} / \mathrm{L}$ throughout the years 2007 to 2012. The determination of BOD at the various sampling stations showed that Ajido recorded the highest BOD value of $152.75 \pm 89.05 \mathrm{mg} / \mathrm{L}$ with the minimum value of $12 \mathrm{mg} / \mathrm{L}$ and a maximum value of $380 \mathrm{mg} / \mathrm{L}$. Marina on the other hand recorded the lowest BOD value of $126.42 \pm 70.73 \mathrm{mg} / \mathrm{L}$ with a minimum value of $9.00 \mathrm{mg} / \mathrm{L}$ and the maximum value of $264.00 \mathrm{mg} / \mathrm{L}$ (Table 1 ). Other stations had levels within the reported values for Ajido and Marina.

\section{Alkalinity \\ The total mean of alkalinity in Badagry Creek for the years 2007 and 2012 was $53.28 \pm 27.85 \mathrm{mg} / \mathrm{L}$ with the minimum value of $12.10 \mathrm{mg} / \mathrm{L}$ and a maximum concentration of}

$160.00 \mathrm{mg} / \mathrm{L}$. However, the year 2003 recorded the lowest alkalinity of $52.23 \pm 17.39 \mathrm{mg} / \mathrm{L}$ with a minimum concentration of $23.00 \mathrm{mg} / \mathrm{L}$ and a maximum of $83.25 \mathrm{mg} / \mathrm{L}$. The sampling station Ajido recorded the highest mean alkalinity concentration of $57.17 \pm 27.07 \mathrm{mg} / \mathrm{L}$ with the minimum concentration of $15.20 \mathrm{mg} / \mathrm{L}$ and a maximum concentration of $148.00 \mathrm{mg} / \mathrm{L}$. Marina station on the other hand recorded the lowest mean alkalinity concentration of $47.81 \pm 29.11 \mathrm{mg} / \mathrm{L}$ with the minimum concentrations of $21.0 \mathrm{mg} / \mathrm{L}$ and a maximum concentration of $155.00 \mathrm{mg} / \mathrm{L}$ (Table 1).

\section{Total Hardness as CaCO3}

The mean total hardness as $\mathrm{CaCO} 3$ concentration in Badagry Creek for the years 2007 and 2012 was 1031. 39 \pm 1632.89 $\mathrm{mg} / \mathrm{L}$. However the minimum hardness concentration was $58.00 \mathrm{mg} / \mathrm{L}$ and the maximum value recorded was $9500.00 \mathrm{mg} / \mathrm{L}$. With respect to the sampling stations Topo recorded the highest concentration of $\mathrm{CaCO} 3$ with a mean value $1476.67 \pm 2585.20 \mathrm{mg} / \mathrm{L}$ with a minimum value of $9020.00 \mathrm{mg} / \mathrm{L}$ and a maximum value of $9500.00 \mathrm{mg} / \mathrm{L}$. On the contrary, Marina recorded the lowest mean value of $\mathrm{CaCO} 3$ of $803.60 \pm 982.54 \mathrm{mg} / \mathrm{L}$ with the minimum value of $90.00 \mathrm{mg} / \mathrm{L}$ and a maximum value of $3000.00 \mathrm{mg} / \mathrm{L}$ (Table 4).

\section{Total Hardness as MGCO3}

The total mean MgC03 concentrations in Badagry Creek for the years 2007 and 2012 was $522.21 \pm 1146.77 \mathrm{mg} / \mathrm{L}$ with the minimum concentration value of $36.00 \mathrm{mg} / \mathrm{L}$ and a maximum value of $9899.00 \mathrm{mg} / \mathrm{L}$ Looking at the variations of MgC03 among the sampling stations, it will be observed that Topo recorded the highest concentration of MgC03 in the month of June with the value of $735.04 \pm 2012.30 \mathrm{mg} / \mathrm{L}$ with the minimum value of $50.00 \mathrm{mg} / \mathrm{L}$ and a maximum value of $9899.00 \mathrm{mg} / \mathrm{L}$. Marina on the other hand recorded the least value of $422.16 \pm 588.39 \mathrm{mg} / \mathrm{L}$ in the month of January with a minimum of $48.00 \mathrm{mg} / \mathrm{L}$ and a maximum value of 1789.00mg/L (Table 1).

\section{Conductivity}

The total mean conductivity value of Badagry creek for the years 2007 and 2012 was $2133.49 \pm 3456.47 \mu \mathrm{S} / \mathrm{cm}$ with a minimum put at $80.10 \mu \mathrm{S} / \mathrm{cm}$ and the maximum of $19690.00 \mu \mathrm{S} / \mathrm{cm}$. With regard to sampling stations, Akarakumo location recorded the highest conductivity value of $2366.33 \pm 3449.59 \mu \mathrm{S} / \mathrm{cm}$ with the minimum value of $85.00 \mu \mathrm{S} / \mathrm{cm}$ and a maximum value of $12,000.00 \mu \mathrm{S} / \mathrm{cm}$. Topo on the other hand recorded the lowest value of $1942.84 \pm 3059.96 \mu \mathrm{S} / \mathrm{cm}$ with minimum value of $80.10 \mu \mathrm{S} / \mathrm{cm}$ and a maximum value of $11188.00 \mu \mathrm{S} / \mathrm{cm}$ (Table 1$)$.

\section{Nitrate}

The total mean concentration of nitrate in Badagry creek for the year 2007 and 2012 was put at $3.29 \pm 2.15 \mathrm{mg} / \mathrm{L}$ with a minimum value of $0.20 \mathrm{mg} / \mathrm{L}$ and a maximum value of 9.50mg/L.

With regards to sampling stations, the highest mean nitrate concentrations was recorded at Topo with a mean value of $3.74 \pm 2.15 \mathrm{mg} / \mathrm{L}$, a minimum value of $0.60 \mathrm{mg} / \mathrm{L}$ and a maximum value of $9.00 \mathrm{mg} / \mathrm{L}$. Akarakumo on the other hand recorded the lowest mean of $2.65 \pm 1.87 \mathrm{mg} / \mathrm{L}$ with the 


\section{International Journal of Science and Research (IJSR) \\ ISSN (Online): 2319-7064 \\ Index Copernicus Value (2013): 6.14 | Impact Factor (2015): 6.391}

minimum value of $0.20 \mathrm{mg} / \mathrm{L}$ and a maximum of $6.50 \mathrm{mg} / \mathrm{L}$ (Table 1).

\section{Phosphate}

The total mean phosphate concentration in Badagry creek for the years 2007 and 2012 was $2.12 \pm 1.99 \mathrm{mg} / \mathrm{L}$ with a minimum value of $0.12 \mathrm{mg} / \mathrm{L}$ and a maximum value of $15.50 \mathrm{mg} / \mathrm{L}$

With respect to sampling stations, Marina recorded the highest mean phosphate concentration of $2.66 \pm 3.24 \mathrm{mg} / \mathrm{L}$ with a minimum value of $0.12 \mathrm{mg} / \mathrm{L}$ and a maximum value of $15.50 \mathrm{mg} / \mathrm{L}$. Akarakumo on the other hand recorded the lowest mean phosphate concentration of $1.64 \pm 1.22 \mathrm{mg} / \mathrm{L}$ with a minimum value of $0.35 \mathrm{mg} / \mathrm{L}$ and a maximum value of $5.20 \mathrm{mg} / \mathrm{L}$ (Table 1$)$

\section{Chemical Oxygen Demand}

The total mean COD concentration for the years 2003 and 2004 was $498.67 \pm 266.01 \mathrm{mg} / \mathrm{L}$ with a minimum COD value of $80.00 \mathrm{mg} / \mathrm{L}$ and a maximum value of $1930.00 \mathrm{mg} / \mathrm{L}$. Regarding sampling stations, Ajido recorded the highest mean COD concentration of $594.67 \pm 409.49 \mathrm{mg} / \mathrm{L}$ with the minimum value of $90.00 \mathrm{mg} / \mathrm{L}$ and a maximum value of $1930.00 \mathrm{mg} / \mathrm{L}$. Akarakumo on the other hand recorded the lowest COD mean value of $464.33 \pm 170.63 \mathrm{mg} / \mathrm{L}$ with a minimum value of $82.00 \mathrm{mg} / \mathrm{L}$ and a maximum value of $722.00 \mathrm{mg} / \mathrm{L}$ (Table 1$)$

\section{Trace Metals}

\section{Zinc}

The total mean zinc concentration for the years 2007 and 2012 was $16.52 \pm 19.74 \mathrm{mg} / \mathrm{L}$ with a minimum value of $0.030 \mathrm{mg} / \mathrm{L}$ and a maximum value of $88.00 \mathrm{mg} / \mathrm{L}$. Regarding sampling stations, Marina recorded the highest zinc concentration of $19.34 \pm 24.79 \mathrm{mg} / \mathrm{L}$ with a minimum value of $0.03 \mathrm{mg} / \mathrm{L}$ and a maximum value of $88.00 \mathrm{mg} / \mathrm{L}$. Ajido station on the other hand recorded the lowest zinc concentration of $13.81 \pm 15.52 \mathrm{mg} / \mathrm{L}$ with a minimum value of $0.03 \mathrm{mg} / \mathrm{L}$ and a maximum value of $48.00 \mathrm{mg} / \mathrm{L}$ (Table 1 ).

\section{Copper}

The total mean copper concentration value for the years 2007 and 2012 was $4.84 \pm 6.63 \mathrm{mg} / \mathrm{L}$ with a minimum value of $0.02 \mathrm{mg} / \mathrm{L}$ and a maximum value of $28.40 \mathrm{mg} / \mathrm{L}$. With respect to sampling stations, it could be observed that Marina recorded the highest mean copper concentration with the value of $5.18 \pm 7.37 \mathrm{mg} / \mathrm{L}$ with the minimum value of $0.02 \mathrm{mg} / \mathrm{L}$ and a maximum value of $28.40 \mathrm{mg} / \mathrm{L}$. Akarakumo station on the other hand recorded the lowest value of $4.65 \pm 5.91 \mathrm{mg} / \mathrm{L}$ with the minimum value of $0.02 \mathrm{mg} / \mathrm{L}$ and a maximum value $022.10 \mathrm{mg} / \mathrm{L}$ (Table 1 )

\section{Lead}

The total mean Lead concentration in Badagry creek was $1.79 \pm 2.13 \mathrm{mg} / \mathrm{L}$ with a minimum value of $0.02 \mathrm{mg} / \mathrm{L}$ and a maximum value of $10.50 \mathrm{mg} / \mathrm{L}$. With regards to sampling stations, Akarakumo station recorded the highest mean lead values of $2.12 \pm 2.54 \mathrm{mg} / \mathrm{L}$, while with minimum value of $0.10 \mathrm{mg} / \mathrm{L}$ and a maximum value of $10.50 \mathrm{mg} / \mathrm{L}$. While Topo station recorded the lowest mean lead value of $1.32 \pm 1.43$ $\mathrm{mg} / \mathrm{L}$ with the minimum value of $0.02 \mathrm{mg} / \mathrm{L}$ and a maximum value of $6.00 \mathrm{mg} / \mathrm{L}$ (Table 1 ).

\section{Chromium}

The total mean chromium concentration in Badagry creek was $0.34 \pm 0.54 \mathrm{mg} / \mathrm{L}$ with a minimum value of $0.04 \mathrm{mg} / \mathrm{L}$ and a maximum value of $3.90 \mathrm{mg} / \mathrm{L}$. With regards to sampling stations, Topo station recorded the highest mean chromium values of $0.39 \pm 0.76 \mathrm{mg} / \mathrm{L}$, with minimum value of $0.05 \mathrm{mg} / \mathrm{L}$ and a maximum value of $3.90 \mathrm{mg} / \mathrm{L}$. While Marina station recorded the lowest mean chromium value $0.30 \pm 0.44 \mathrm{mg} / \mathrm{L}$ with the minimum value of $0.04 \mathrm{mg} / \mathrm{L}$ and a maximum value of $1.60 \mathrm{mg} / \mathrm{L}$ (Table 1 ).

\section{Cadmium}

The total mean cadmium concentration in the Badagry creek for the year 2007 and 2012 was $0.08 \pm 0.11 \mathrm{mg} / \mathrm{L}$ with the minimum value of $0.00 \mathrm{mg} / \mathrm{L}$ and a maximum value of 0.50 $\mathrm{mg} / \mathrm{L}$.

As regards sampling stations, Akarakumo and Ajido recorded the highest mean value of $0.10 \pm 0.13 \mathrm{mg} / \mathrm{L}$ and while Topo and Marina recorded the lowest value of $0.07 \pm 0.09 \mathrm{mg} / \mathrm{L}$ with minimum value of 0.01 and a maximum of 0.33 and 0.43 respectively $\mathrm{mg} / \mathrm{L}$ (Table 1 ).

\section{Discussion}

\section{Temperature}

The temperature range of Badagry creek was $26^{\circ} \mathrm{C}-31^{\circ} \mathrm{C}$. It is believed that water temperature controls the metabolic rate and the reproductive activities of aquatic life. Standard set by the environmental protection agency (Federal Environmental Protection Agency FEPA, 1991) for acceptable level of temperature in drinking water is $32^{\circ} \mathrm{C}$ maximum. Comparing this to the result obtained from Badagry creek water sample, it can be said that the temperature of the creek water is still normal, although lower than the accepted standard. High water temperatures may affect fish metabolic process, thereby causing stress on the fish, while their physiologic demand for oxygen increases (Francis-Floyd, 2003).Not only that, the growth, feeding, reproduction and migratory behavior of aquatic organisms including fish and shrimps are greatly influenced by the temperature of water (Lagler et al., 1977; Suski et al., 2006; Fey, 2006; Crillet and Quetin, 2006).

\section{Turbidity}

With higher levels of turbidity, water loses its ability to support a diversity of aquatic organisms. Water becomes warmer as suspended particles absorb heat from the sunlight and cause oxygen levels to fall. Photosynthesis decreases because less light penetrates the water, ((Boulton and Brock 1999; ANZECC/ARMCANZ 2000) resulting in even further drops in oxygen levels. The combination of warmer water, less light and oxygen depletion makes it impossible for some forms of aquatic life to survive. In another study by Blanch et al (1998) highly turbid water was found to prevent the growth of Vallisneria americana in the Murray Darling. Decreased water temperatures due to decreased light

Turbidity also limits fish vision, which can interfere with social behaviour (Berg and Northcote 1985), foraging (Gregory and Northcote 1993; Vogel and Beauchamp 1999) and predator avoidance (Miner and Stein 1996; Meager et al. 2006). This can have varying effects on fish growth and 


\section{International Journal of Science and Research (IJSR) \\ ISSN (Online): 2319-7064 \\ Index Copernicus Value (2013): 6.14 | Impact Factor (2015): 6.391}

survival, depending on a range factors such as ambient light levels and depth; relative visual sensitivities of predators and prey, and non-visual sensory abilities

\section{Dissolved Oxygen}

Decreases in the dissolved oxygen levels can cause changes in the types and numbers of aquatic macro invertebrates, plants and animals living in an ecosystem. However, dissolved oxygen levels change and vary according to the time of day, the weather and the temperature. A decrease in the dissolved oxygen levels is usually an indication of an entry of some organic pollutant.

Concentrations below $5 \mathrm{mg} / \mathrm{l}$ may adversely affect function and survival of biological communities and below $2 \mathrm{mg} / \mathrm{l}$ can lead to death of most fishes (Water Quality Assessments, 1996). Behaviorally, fish may avoid low dissolved oxygen conditions by physically moving out of an area. Finally, low oxygen levels can also increase toxicity of contaminants to anadromous fish, including ammonia, zinc, lead, and copper (Colt et al 1979, Davis 1975).

\section{Conductivity ( $\boldsymbol{\mu S} / \mathbf{C M})$}

Conductivity values reflect that the creek is brackish water, and is relatively high when compared to the very low conductivities. Conductivity values are indication of mineralization and nutrient level of the water (Uka and Chukwuka 2007).

Low Conductivity (0 to $200 \mu \mathrm{S} / \mathrm{cm}$ ) is an indicator of pristine or background conditions. Mid range conductivity (200 to $1000 \mu \mathrm{S} / \mathrm{cm}$ ) is the normal background for most major rivers. Conductivity outside this range could indicate that the water is not suitable for certain species of fish or bugs. High conductivity (1000 to $10,000 \mu \mathrm{S} / \mathrm{cm}$ ) is an indicator of saline conditions. Waters that have been heavily impacted by industry can fall into this range. (Wetzel, 1983)

\section{The Chemical Oxygen Demand COD}

The chemical oxygen demand (COD) is a measure of the total quantity of oxygen required to oxidize all organic materials into carbon dioxide and water (Barnes et al., 1998). It does not differentiate between biologically available and inert organic matter. The high level of the COD documented indicates that the river is polluted. The contamination may be due to domestic materials or substances that are released into the river body either directly or indirectly.

\section{Biochemical Oxygen Demand (BOD)}

Biochemical oxygen demand (BOD) is a measure of the quantity of oxygen consumed by micro-organisms during the decomposition of organic matter. It was reported that a high BOD generally indicates the presence of excessive amounts of organic matter (EPA, 1987). This high BOD level may cause acceleration in bacterial growth and consumption of oxygen level in the river (Fafioye, 2011).

\section{PH}

$\mathrm{PH}$ value of the water sample in the river falls within the $\mathrm{pH}$ of water for domestic use (6 to 9 ) of the target water quality range (TWQR) (DWAF, 1996a). Most aquatic species are sensitive to changes in $\mathrm{pH}$, likewise some streams have a neutral to slightly basic $\mathrm{pH}$ of 6.9 to 8.5 . If stream water has a $\mathrm{pH}$ less than 5.5, it may be too acidic, while stream water with a $\mathrm{pH}$ greater than 8.6 may be too basic for fish to survive inside (Barnes et al., 1998). Therefore, the recorded $\mathrm{pH}$ of water of Azikwe River can be said to be normal for its organism.

The $\mathrm{pH}$ higher than 7, but lower than 8.5 is ideal for biological productivity while $\mathrm{pH}$ lower than 4 is detrimental to aquatic life (Abowei, 2010). Most organisms including shrimps do not tolerate wide variations of $\mathrm{pH}$ over time and if such conditions persist death may occur.

\begin{abstract}
Alkalinity
Alkalinity which has the capacity to neutralize acids is examined in conjunction with $\mathrm{pH}$ (Barnes et al., 1998). Since the $\mathrm{pH}$ of the river is 7.75 which is slightly higher than neutral and tends toward alkaline, thus, it can be said that the river water is slightly rich in alkaline. The World Health Organisation documented that highly alkaline waters are unpalatable and can cause gastrointestinal discomfort (WHO, 1984). Alkalinity is slightly related to salinity of a river. An increase in the alkalinity of water indicates an increase in the salinity of such river water. The salinity of the river water sample was $60 \mathrm{mg} / \mathrm{l}$, which is still normal for salt concentration in fresh water.
\end{abstract}

\section{Phosphate}

The phosphate level of the water sample is $5.02 \mathrm{mg} / \mathrm{l}$ and is specific since there is no effective standard for phosphorus (EPA, 1987). However, the nitrates concentra-tion of the creek water sample was $98.60 \mathrm{mg} / \mathrm{l}$, this is too high since the standard level of nitrate in fresh water bodies is $88.60 \mathrm{mg} / \mathrm{l}$ giving a difference of $10 \mathrm{mg} / \mathrm{l}$ (EPA, 1987). In view of this, it can be deduced that the nitrate concentration in the analysed river water is significantly high. The ecological health effects of this may be severe on the users. The concentration level of sulphate in the river is $14.20 \mathrm{mg} / \mathrm{l}$. According to the standard regulations stated (EPA, 1987), $250 \mathrm{mg} / \mathrm{l}$ was recommended as the standard level of sulphate in fresh waters. In comparism, it can be documented that the concentration of sulphate in the river is minimal and will support life of its organisms. The concentration level of zinc $(0.379 \mathrm{mg} / \mathrm{kg})$ recorded in the river water sample is lower than the target water quality range of $0.00-3.00 \mathrm{mg} / \mathrm{l}$ zinc recommended for domestic use (QDWS, 1998). This showed that the water from the river could be used for domestic purpose.

The Kerschmann (2000), which by conversion is equivalent to $0.50 \%$. Similarly, a higher level of $0.30 \%$ phosphate in fish was reported in another work (Hunt et al., 2001). However the values recorded for this experiment cannot pose any health problem or risk, because the percentages of phosphate in the fish sample are minimal. The sulphate concentrations of 2.70 and $2.58 \%$ for $\mathrm{T}$. nilotica and S.aurita respectively fall within the standard level (FAO, 2001). 


\section{International Journal of Science and Research (IJSR) \\ ISSN (Online): 2319-7064}

Index Copernicus Value (2013): 6.14 | Impact Factor (2015): 6.391

Table 1: The physicochemical characteristics of the four study stations SAMPLING SITES

\begin{tabular}{|c|c|c|c|c|c|c|}
\hline PARAMETERS & & Akarakumo & Ajido & Topo & Marina & FEPA STD \\
\hline \multirow{3}{*}{ Temp OC } & Mean & $27.2 \pm 0.95$ & $27.34 \pm 0.87$ & 27.76 & $27.79 \pm 1.08$ & \\
\hline & Min & 26.00 & 26.50 & 26.00 & 27.00 & $32^{\mathrm{O}} \mathrm{C}$ \\
\hline & Max & 30.00 & 30.00 & 31.00 & 31.00 & \\
\hline \multirow{3}{*}{ Turbidity(NTU) } & Mean & $13.63 \pm 3.92$ & $12.11 \pm 3.60$ & $13.84 \pm 5.73$ & $13.26 \pm 3.43$ & \\
\hline & Min & 8.00 & 6.00 & 8.00 & 8.00 & $10 \mathrm{TNU}$ \\
\hline & Max & 23.00 & 21.00 & 28.00 & 20.00 & \\
\hline \multirow[b]{3}{*}{$\mathrm{pH}$} & Mean & $7.44 \pm 0.73$ & $7.45 \pm 0.63$ & $7.52 \pm 0.76$ & $7.59 \pm 1.09$ & $6.9-9.0$ \\
\hline & Min & 6.75 & 6.40 & 6.60 & 6.65 & \\
\hline & Max & 10.10 & 9.30 & 10.20 & 12.00 & \\
\hline \multirow{3}{*}{ Dissolved oxygen (mg/L) } & Mean & $4.64 \pm 0.45$ & $4.57 \pm 0.39$ & $4.66 \pm 0.51$ & $4.62 \pm 0.44$ & \\
\hline & Min & 3.80 & 4.10 & 3.80 & 4.00 & $5.0 \mathrm{mg} / \mathrm{l}$ \\
\hline & Max & 5.60 & 5.20 & 5.60 & 5.40 & \\
\hline & Mean & $2366.33 \pm 3449.59$ & $1964.73 \pm 3109.90$ & $1942.84 \pm 3059.96$ & $2260.04 \pm 4274.55$ & \\
\hline Conductivity ( $\mu \mathrm{S} / \mathrm{cm})$ & $\begin{array}{l}\text { Min } \\
\text { Max. }\end{array}$ & $\begin{array}{c}85.00 \\
12000.00\end{array}$ & $\begin{array}{c}93.00 \\
71920.00\end{array}$ & \begin{tabular}{|c|}
80.10 \\
11188.00
\end{tabular} & $\begin{array}{c}85.00 \\
19690.00\end{array}$ & $250(\mu \mathrm{S} / \mathrm{cm})$ \\
\hline \multirow{3}{*}{ Chemical Oxygen Demand } & Mean & $448.47 \pm 183.22$ & $603.26 \pm 457.65$ & $464.16 \pm 233.57$ & $461.42 \pm 208.39$ & \multirow{3}{*}{$80 \mathrm{mg} / \mathrm{L}$} \\
\hline & Min & 82.00 & 90.00 & 85.00 & 80.00 & \\
\hline & Max & 722.00 & 1930.00 & 993.00 & 856.00 & \\
\hline \multirow{3}{*}{$\mathrm{BOD}(\mathrm{mg} / \mathrm{L})$} & Mean & $128.83 \pm 66.18$ & $152.75 \pm 89.05$ & $131.71 \pm 70.38$ & $126.42 \pm 70.73$ & \multirow[b]{2}{*}{$15.0 \mathrm{mg} / \mathrm{L}$} \\
\hline & Min & 10.00 & 12.00 & 10.00 & 9.00 & \\
\hline & Max & 244.00 & 380.00 & 290.00 & 255.00 & \\
\hline \multirow{3}{*}{ Alkalinity (mg/L) } & Mean & $55.92 \pm 27.95$ & $57.75 \pm 29.59$ & $52.14 \pm 32.68$ & $48.16 \pm 32.12$ & \\
\hline & Min & 12.10 & 15.20 & 15.20 & 21.00 & $100-150 \mathrm{mg} / \mathrm{L}$ \\
\hline & Max & 140.00 & 148.00 & 160.00 & 155.20 & \\
\hline \multirow{3}{*}{ Total Hardness as CaCo3 n(mg/L) } & Mean & $919.91 \pm 1282.44$ & $793.17 \pm 1167.49$ & $1153.74 \pm 2130.60$ & $742.12 \pm 994.29$ & $500 \mathrm{mg} / \mathrm{L}$ \\
\hline & Min & 90.10 & 58.00 & 90.20 & 90.00 & \\
\hline & Max & 3330.00 & 3325.00 & 9000.00 & 3000.00 & \\
\hline \multirow{3}{*}{ Total hardness as MgCO3 (mg/L) } & Mean & $496.89 \pm 758.06$ & $439.21 \pm 729.77$ & $828.47 \pm 2252.20$ & $395.06 \pm 564.17$ & $500 \mathrm{mg} / \mathrm{L}$ \\
\hline & Min & 42.00 & 36.00 & 50.00 & 48.00 & \\
\hline & Max & 2260.00 & 2324.00 & 9899.00 & 1603.00 & \\
\hline \multirow{3}{*}{ Nitrate (mg/L) } & Mean & $2.64 \pm 1.92$ & $3.34 \pm 2.12$ & $3.94 \pm 2.26$ & $3.79 \pm 2.69$ & $50 \mathrm{mg} / \mathrm{l}$ \\
\hline & Min & .20 & .60 & .80 & .60 & \\
\hline & Max & 6.50 & 8.10 & 9.00 & 9.50 & \\
\hline \multirow{3}{*}{ Phosphate (mg/L) } & Mean & $1.72 \pm 1.33$ & $2.20 \pm 1.70$ & $2.12 \pm 1.23$ & $2.92 \pm 3.61$ & \\
\hline & Min & .35 & .40 & .23 & .12 & $5.0 \mathrm{mg} / \mathrm{L}$ \\
\hline & Max & 5.20 & 6.80 & 4.30 & 15.50 & \\
\hline
\end{tabular}

Table 2: The Concentration level of metals analyzed on Badagry creek water sample

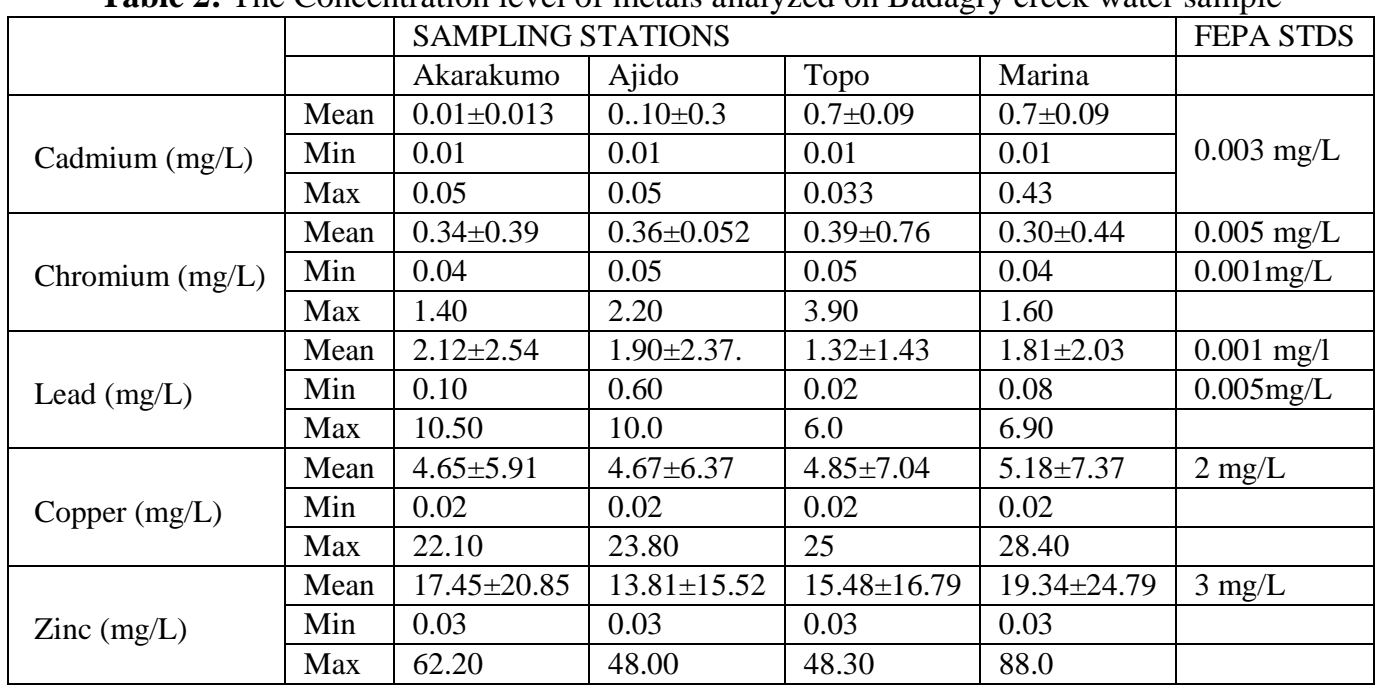

\section{Volume 5 Issue 4, April 2016}




\section{International Journal of Science and Research (IJSR) \\ ISSN (Online): 2319-7064 \\ Index Copernicus Value (2013): 6.14 | Impact Factor (2015): 6.391}

Basically, biological activities of freshwater bodies are regulated by various Physico-chemical factors viz., turbidity, temperature, $\mathrm{pH}$, electrical conductivity, total hardness, nitrates, phosphates etc. This is observed in Badagry Creek and had greatly affected the water quality of the creek.

The results obtained at the above mentioned sampling stations are given in table 1 . It was found that the following parameters namely turbidity, conductivity, chemical Oxygen Demand, Biological Oxygen Demand, Total Hardness calcium carbonate, and lead were high in concentration when compared with FEPA and WHO standard. As with oxygen value, the concentration value was very low. DO. is the important parameter in assessing water quality and ret1ects the physical and biological processes, prevailing in the water. Good water should have the solubility of oxygen 7.6 and $7.0 \mathrm{mg} / \mathrm{l}$ at $30^{\circ} \mathrm{C}$ and $35{ }^{\circ} \mathrm{C}$ respectively (Kudesia ,1985). The low value of dissolved oxygen in the creek in some period of the year could be due to the use of oxygen in biodegradation of organic matters which are present in the creek (Boyd, 1981).

The high level of total BOD,COD,Turbidity, total hardness, electrical conductivity low dissolved oxygen content recorded in the study stations could be an indication of the deteriorating water quality and probably resulted from the discharges of industrial and domestic wastes into the creek through the land based anthropogenic inputs and other sources. Similarly, Ajao and Fagade, (1990); Akpata et al; (1993), recorded, high biochemical oxygen demand, low dissolved oxygen content and heavy microbial load at organically polluted sites in the Lagos Lagoon.

According to FEPA (1991) $0-75 \mathrm{mg} / \mathrm{l}$ is soft water and $300 \mathrm{mg} / \mathrm{l}$ is hard water. This result showed that Badagry Creek was hard water. Water hardness is mainly caused by the presence of calcium and magnesium and is expressed as the equivalent quantity of calcium carbonate which is reported by Bartram et. al (1996) to be abundant in the earth's crust and hence a common constituent of natural water in Badagry creek. Not only that, flowing water as Badagry creek could flow through areas of softer rocks, which supply at least some calcium to the water. Report of Hynes (1960) show that, not many animals are affected adversely by hard water but some; particularly those which form shells requires at least a minimum amount of calcium. Such creatures include shrimps and most other crabs. This is in line with the report of Jones (1948) that most of these animals are found in large numbers in nearby hard stream of Clydach. Bernard (2005) reported that hardness does not cause any severe effects for organisms, it only is known to cause the existence of kidney stones Badagry Creek is ranked as very hard for the value was 180 and above.

Other parameters such as temperature, $\mathrm{pH}$ Alkalinity, Total water hardness with magnesium carbonate, nitrate and phosphate were within the acceptable limit stipulated by FEPA, (1991) and WHO, (2004). However, the values are very significant at $\mathrm{P}<0.05)$. This indicate that the values recorded could have a lot of influence the biological and chemical activities of Badagry creek
Heavy metals considered in this analysis are cadmium, chromium, lead, copper and zinc. Of all, lead is higher than acceptable limit set by FEPA and WHO standards, whereas, others are within the limit. The high level of lead concentration in Badagry creek called for concern as most of the lead pollution in the environment could be traced to industrial production processes and their emissions, road traffic with leaded petrol, the smoke and dust emissions of coal and gas-fired power stations, the laying of lead sheets by roofers as well as the use of paints and anti-rust agents .This is similar to the report of GENF (1989), Nriagu and Coker, (1980) and (Ramamoorthy and Rust, 1978). Research further revealed that years of sampling and source i.e. water and sediment is significant in the distribution of lead in the environment at $(\mathrm{P}<0.05)$ confidence limit. However sampling stations have no influence on the lead distribution (Table, 1)

There was no significant difference $(\mathrm{P}>0.05)$ in the mean values of all the Physico-chemical parameters in the four sampling stations (Akarakumo, Ajido, Topo and Marina) throughput the sampling period.

\section{Conclusion}

This study showed that habitat modification of Badagry Creek is relatively on the increase. The most common forms of habitat modification are: riparian vegetation disturbance or removal, bank reshaping and accelerated erosion, reduction and trampling of stream banks and bed by stock This may significantly adversely affect sensitive native fish. Like other studies in New Zealand, by Collier and Winterbourn, (2001) this group of fish appears ill-adapted to cope with much habitat disturbance.

\section{Acknowledgements}

My sincere thanks go to the fishermen and entire household of Oba of Topo and Akarakumo for allowing us to collect samples needed for this research.

\section{References}

[1] Abowei, JFN., Salinity, dissolved oxygen, $\mathrm{pH}$ and surface water temperature conditions in Nkoro River, Niger Delta, Nigeria. Adv. J. Food Sci. Technol., 2(1): 16-21. (2010)

[2] Agriculture and Resource Management Council of Australia and New Zealand. (2000),

[3] Ajao EA. and Fagade S. O. A study of sediment and communities in Lagos Lagoon, Nigeria. Oil and ChemicalPollution. (1990).

[4] Akpata, TVI.; Oyenekan, J.A. and Nwankwo, D.I. Impacts of Organic Pollution on the Bacterial, Plankton and Benthic populations of the Lagos Lagoon Nigeria. International Journal of Ecology and Environmental Sciences. 19: 73 - 82. (1993).

[5] ANZECC/ARMCANZ Australian and New Zealand Guidelines for Fresh and Marine

[6] APHA, AWWA \& WEF. Standard methods for the examination of water and wastewater. American Public Health Association, American Water Works 


\section{International Journal of Science and Research (IJSR) ISSN (Online): 2319-7064 \\ Index Copernicus Value (2013): 6.14 | Impact Factor (2015): 6.391}

Association and Water Environment Federation, Washington, USA, 2-1 to 2-3. (1995)

[7] Barnes KH, Meyer JL, Freeman BJ Sedimentation and Georgia's Fishes: Anal. Exist. Inform. Future Res. 126(7):23-42. (1998).

[8] Bartram, J and Balance, R. [Eds] Water Quality Monitoring. A Practical Guideto the Design and Implementation of Freshwater Quality Studies andMonitoring Programmes. Published on behalf of UNEP and WHO by E \& FN Spon, London, 383 pp

[9] Blanch, SJ., Ganf, GG. and Walker, KF., 'Growth and recruitment in Vallisneria americana as related to average irradiance in the water column', Aquatic Botany, vol. 61, pp. 181-285. (1998)

[10]Boulton, AJ. and Brock, AJ., Australian Freshwater Ecology Processes and Management,

[11] Boyd, CE. (1980).Water quality management in warm water fish ponds. Auburn University, Agric Experiment Station. Publ. Auburn University. (1996)

[12]Chandler, R D. Estimating annual urban nonpoint pollution loads. Journal of Management in Engineering, 10, 6, 50-59. (1994)

[13] Collier, KJ. and Winterbourn, M.J. New Zealand Stream Invertebrates: Ecology and Implications for Management, New Zealand Limnological Society. (2001)

[14] Colt, JS. Mitchell, G. Tchobanoglous, and A. Knight.. The use and potential for aquatic species for wastewater treatment: Appendix B, the environmental requirements of fish. Publication No. 65, California State Water Resources Control Board, Sacramento, CA. (1979)

[15] Crillet, C. and P. Quetin, Effect of temperature changes on the reproductive cycle of leach in Lake George from 1983 to 2001. J. Fish Biol., 69: 518-524. (2006).

[16] Davis, JC. Minimal dissolved oxygen requirements of aquatic life with emphasis on Canadian species: a review. Journal of Fisheries Research Board Canada. 32(12), 2295-2332. (1975)

[17]DWAF Water Quality Guideline, Domestic use. (2nd edition), DWAF. Pretoria 1(1):14-64. (1996a).

[18] Ellis, JB. and Hvitved-Jacobsen, T. Urban drainage impacts on receiving waters. Journal of Hydraulic Research, 34, 6, 771-783. (1996)

[19]EPA : Water Quality and Cean Water Act. Report: pp. 32-38. (1987).

[20]Fafioye OO Preliminary Studies on Water Characteristics and BacteriaPopulation in High Yield Kajola Fish Ponds .J. Agric. Ext. Rural Dev. (JAERD) 3(3):68-71. (2011).

[21]FAO The composition of Fish Muscle and Flesh. Food and Agricultural Organisation, Corporate Document Repository. 32-38.(2001).

[22]FEPA 1991 Guidelines and Standards for Environmental Pollution Control in Nigeria.

[23] Fey, DP., The Effect of temperature and somatic growth on otolith growth. The discrepancy between to dupeid species from similar environment. J. Fish Riot., 69: 794806.(2006).

[24]Francis-Floyd R Fact Sheet FA 27. A series of the Department of Fisheries and Aquaculture, Florida Cooperative Extension Service, Instit. Food Agric. Sci. Univ. Florida. p 36. (2003).

[25] Gleneagles Publishing, Glen Osmond, Australia. (1999)
[26] Hassan, M., Effect of pond fertilization by broiler droppings on growth performance and meat quality of major carps. Ph.D. Thesis, Agric. Univ. Faisalabad, pp: 196.

[27]Hunt AL, KimJ S, Park JW, Schnee R Aquatic Food Products; Quality Processing, antioxidants and surimi. Session. 63:11. (2001).

[28] Hynes, HBN. (1970). The ecology of running waters. Liverpool U. P. xxiv+555. ( 1998).

[29]Karr, JR. and Chu, EW. Sustaining living rivers. Hydrobiologia, 422, 1-14. (2000)

[30] Kerschmann JD. Nutrition Almanac.8th editions, 2000 pp. 210-211. (1983).

[31] Kudesia, VP. Water pollution. Pragati Prakashan, Meerut(1985)

[32] Lagler, F.L., J.E. Baolah and R.R. Miller, Ichthyology. The Study of Fishes. 2nd Edn., John

[33]Latif, M., Comparison of Physico-chemical and biological aspects of two fish ponds fertilized with broiler droppings and N: P: K (25:25:0). M.Sc. Thesis Agric. Univ., Faisalabad, pp: 104. (1990).

[34] Mahboob, S. and AN. SheriEffect of fertilizer and artificial feed on the seasonal distribution of planktonic life in fish. ,(2001).

[35] Mahboob, S. Seasonal changes in planktonic life and water chemistry of Ajmal fish farm, Samundri road, Faisalabad. M.Sc. Thesis Agric. Univ., Faisalabad, pp: 89. .(1986).

[36] Mahboob, S., Influence of fertilizer and artificial feed on the growth performance in composite culture of major, common and some Chinese carps. Ph. D. thesis Agric. Univ., Faisalabad. pp: 261. (1992).

[37] Mahboob, SAN. Sheri, M. B. Sial and M. Javed, Influence of physico-chemical factors on the dray weight of planktonic biomass in a commercial fish farm. Pak. J. Agric. Sci., 25:271-224. (1988b).

[38] Mahboob, SAN. Sheri, MB. Sial and M. JavedThe dry weight of planktonic biomass including the phytoplankton and zooplankton gave a vivid picture. (1988a)

[39] Mahboob, SAN. Sheri., MB. Sial., M. Javed and M. Afzal, Seasonal changes in physico-chemistry and planktonic life of a commercial fish farm. Pak. J. Agric. Sci., 25:22-27. (1988).

[40] McCormick, PV. and Cairns, J. Algae as indicators of environmental change. Journal of Applied Phycology, 6, 509-526. (1994)

[41] Moog, O. and Chovanec, A. Assessing the ecological integrity of rivers: walking the line among ecological, political and administrative interests. Hydrobiologia, 422, 99-109. (2000)

[42] QDWS (Assessment Guide (2nd edition). Department of Water Affairs and Forestry Department of Health and Water Research Commission, Pretoria. 1(2):6384.1998).

[43] Suski, CD., SS. Killen, JD. Keiffer and BI. Tufts,. The influence of environmental temperature and oxygen concentrations on the recovery of large mouth bass fine exercise. Implications for live release tournaments. J. Fish Biol., 68: 120-136. (2006)

[44]UKA, UN. and Chukwuka, KS. Effect of water Hyacinth ingestation on the physicochemical

\section{Volume 5 Issue 4, April 2016




\section{International Journal of Science and Research (IJSR) \\ ISSN (Online): 2319-7064}

Index Copernicus Value (2013): 6.14 | Impact Factor (2015): 6.391

characteristics of AWBA Reservoir, Ibadan SouthWest, Nigeria. J. of Biol. Sci. 7(2): 282 - 287. (2007).

[45] Water Quality Assessments. Water Quality assessments: A guide to the use of biota, sediments and water in environmental modeling. Ed. D. Chapman. Published on behalf of UNESCO United Nations Education, Scientific, and Cultural Organization; WHO World Health Organization; UNEP United Nations Environmental Program. Chapman \& Hall, London. (1996)

[46] Water Quality, Australia and New Zealand Environment and Conservation Council and the

[47] Wetzel, RG. Limnology, 2nd edition. Saunders College Publishing. $760 \mathrm{pp}$.

[48] WHO :Guidelines for Drinking Water Quality, Health Criteria and Supporting Information. World Health Organisation. Geneva pp. 85-110. (1984).

[49] WHO,. Guidelines for Drinking Water Quality, Third Edition. Volume 1: Recommendations. World Health Organization, Geneva. (2004). 